\title{
Characteristic bacteria associated with surfaces of coralline algae: a hypothesis for bacterial induction of marine invertebrate larvae
}

\author{
Craig R. Johnson ${ }^{1, *}$, David G. Muir ${ }^{1}$, Anne L. Reysenbach ${ }^{1}$ \\ ${ }^{1}$ Institute of Marine Studies, Zoology Department, University of Cape Town, Rondebosch 7700, South Africa
}

\begin{abstract}
Crustose coralline algae (CCA) induce high rates of settlement and metamorphosis in a diversity of marine invertebrate larvae. It is often assumed that inducers associated with CCA are algal in origin, but an alternative hypothesis is that they originate from bacteria on the algal surface. Because many species manifest specificity in settling on CCA, a necessary condition of the hypothesis of bacterial origin is that bacterial assemblages on CCA are distinctive. Bacteria isolated from surfaces of 2 South African species of CCA (Sporolithon sp. and Clathromorphum sp.). 2 seawater samples collected adjacent to the CCA, and ground-glass slides incubated next to the corallines were examined for 34 morphological and physiological characters. Bacteria from the 2 CCA were distinct from those from other microhabitats and from each other, whereas isolates from the 2 seawater samples were similar, and those from glass slides were more similar to seawater populations than to coralline-associated bacteria. Bacteria from corallines were distinguished by narrower temperature ranges for growth, and in general, inability to (1) utilize glucose, (2) hydrolyse complex carbohydrates and urea, (3) utilize simple amino acids, and (4) reduce nitrate. These characteristics and the distributions of bacteria on crust surfaces suggest that epiphytic bacteria may utilise compounds from the algae for growth. Bacteria on Sporolithon sp. grew mostly from within recently damaged cells, whereas on Clathromorphum sp. they proliferated on a mucus-like matrix on its surface. For some strains the association of bacteria with host alga may be specialised. These results are consistent with the hypothesis of bacterial origin of inducers associated with CCA, but they do not provide a critical test and thus do not resolve the question of algal or bacterial origin of inducers. In examining both hypotheses, we suggest methods to critically discern among these 2 alternatives. There was no trace of free GABA ( $\gamma$-aminobutyric acid) or L-DOPA (L- $\beta-3,4$ dihydroxyphenylalanine) in cell-free extracts of either species of South African coralline algae or in bacteria isolated from the corallines and the other microhabitats. This finding supports other work suggesting that these compounds have no ecological relevance as inducers.
\end{abstract}

\section{INTRODUCTION}

Settlement and metamorphosis of larvae of a large number of marine invertebrates are known to be influenced by crustose coralline algae (CCA). In some species recruitment is inhibited by CCA (barnacles, Padilla 1981; bryozoans, polychaetes, tubicolous amphipods, Breitburg 1984), but there are many more reports of coralline algae enhancing settlement and/or recruitment (soft octocorals, Sebens 1983a, bi scleractinian corals, Morse et al. 1988; polychaetes, Gee 1965; abalone, Morse et al. 1979, Morse \& Morse 1984a;

\footnotetext{
- Present address and address for correspondence: Department of Zoology, University of Queensland, St. Lucia, Queensland 4072, Australia
}

limpets, Steneck 1982; chitons, Barnes \& Gonor 1973, Morse et al. 1979, Rumrill \& Cameron 1983; asteroids, Yamaguchi 1973, Barker 1977, Johnson et al. 1991; sea urchins, Pearce \& Scheibling 1988, Rowley 1989). Because of the importance of recruitment patterns of marine invertebrates to the structure and dynamics of marine ecosystems, the nature of mechanisms inducing or inhibiting settlement is of considerable interest.

It is often assumed, tacitly or otherwise, that inducers associated with CCA are produced by the alga. For example, in perhaps the most extensively studied CCA/larva interaction, algal origin has been posited for CCA-associated inducers of settlement of larvae of Pacific red abalone (Haliotis rufescens). In laboratory trials, $H$. rufescens larvae demonstrate substratum specificity for any one of several species of intact CCA, 
and it has been shown that the morphogenetic activity in surface layers of inductive CCA resides in a small oligopeptide complexed to colourless proteins, which are thought to be algal in origin (Morse \& Morse 1984a, Morse et al. 1984. Morse 1985). However it needs emphasizing that the idea of algal origin of inducers has not been tested critically (although present evidence does not suggest otherwise), and definitive data to support the idea are lacking

An alternative hypothesis is that morphogenic substances associated with intact CCA are produced by bacteria growing on the plant surface and not by the alga itself. Testing this notion must demonstrate (1) that bacterial populations on coralline algae are different to those from other marine microhabitats, and (2) that epiphytic bacteria on CCA can induce settlement and metamorphosis of larvae. Uniqueness of assemblages of epiphytic bacteria on CCA is necessary to the hypothesis because larvae of many species manifest a degree of substratum specificity in settling and metamorphosing on CCA at much higher rates than on films of non-specific bacteria growing on biologically inactive hard substrata (Gee 1965, Barnes \& Gonor 1973, Barker 1977, Rumrill \& Cameron 1983, Sebens 1983a, Morse \& Morse 1984a, Morse et al. 1988, Johnson et al. 1991). The principal aim of this study was to determine whether bacteria epiphytic on surfaces of CCA are distinct from those from other marine microhabitats. We did this by comparing properties of bacteria isolated from 2 South African species of corallines (Sporolithon sp. and Clathromorphum sp.), from 2 seawater samples collected within $10 \mathrm{~mm}$ of the corallines, and from ground-glass slides incubated alongside the corallines.

Laboratory experiments have demonstrated induction of settlement and/or metamorphosis of larvae of several marine invertebrates by both CCA and low concentrations of GABA ( $\gamma$-aminobutyric acid) (abalone, Hahn 1989 and references; chiton, Rumrill \& Cameron 1983; sea urchin, Pearce \& Scheibling 1988). Other neuroactive substances found to induce settlement, or implicated in the induction, of marine invertebrate larvae are L-DOPA (L- $\beta$-3,4-dihydroxyphenylalanine) and DOPA-related compounds (Cooper 1983, Jensen \& Morse 1984, 1990, Coon et al. 1985, Weiner et al. 1985, Pawlik 1990), although in no case have these been associated with CCA. However, GABA has not been found in extracts of CCA (implicit in Morse \& Morse 1984b, and confirmed by A. Morse pers. comm.) and there is no evidence that it plays a role in induction in nature, nor is there any documentation of the ecological relevance of free L-DOPA as a morphogen. To provide further indication as to their role as inducers in nature, we assayed for GABA and L-DOPA in cell-free extracts of (1) both species of South African corallines, and (2) the bacteria isolated from them and from adjacent microhabitats.

\section{METHODS}

Sampling sites and identification of corallines. Crustose coralline algae from which bacteria were isolated were collected in subtidal kelp forests at Oude$\mathrm{kraal}\left(33^{\circ} 58^{\prime} \mathrm{S}, 18^{\circ} 21^{\prime} \mathrm{E}\right)$ on the west coast of the Cape Peninsula, South Africa, during April-May 1987. Corallines were identified tentatively as a species of Sporolithon (= Archaeolithothamnium) and one of Clathromorphum (Y. Chamberlain pers. comm.), but they have not been described formally.

Culture and isolation of bacterial strains. Bacteria were isolated from 5 microhabitats, viz. surfaces of Sporolithon sp. and Clathromorphum sp., surfaces of ground-glass microscope slides incubated for $11 \mathrm{~d}$ adjacent to the Clathromorphum sp. which was sampled, and from 2 seawater samples collected $\leq 10 \mathrm{~mm}$ above the surface of the corallines sampled. The glass slides were used to provide a biologically inert hard surface for microbial colonization. They were presterilised and maintained aseptically until positioned at the incubation site. Samples of Sporolothin sp. and seawater were collected at $2 \mathrm{~m}$ depth, and the Clathromorphum sp., second seawater, and glass slide samples at $8 \mathrm{~m}$ depth. Seawater was collected into sterile syringes, whereas coralline algae were chipped from the substratum with cold chisels and collected into sterile jars. The algae and glass slides were rinsed vigorously in sterile seawater (SSW) before transferring to SSW on ice for transport.

To isolate bacteria from the surface of the coralline algae, a suspension was prepared by chipping off small flakes and grinding them in SSW (ratio algae:SSW = $1: 3$ to $1: 6$ by wt) with a pestle and mortar. Care was taken to exclude flakes whose undersurfaces may have been contaminated by the activities of boring organisms. A similar suspension was prepared from the glass slides by scraping their surfaces and homogenising the scrapings in SSW with a glass tissue-homogeniser. Samples $(0.1 \mathrm{ml})$ of the seawater, and from a serial dilution series of each suspension, were spread onto seawater-agar plates which were incubated at $15^{\circ} \mathrm{C}$ (solid growth medium contained 4 parts $0.2 \mu \mathrm{m}$-filtered seawater, 1 part glass-distilled water, $0.1 \% \mathrm{w} / \mathrm{v}$ peptone (Difco), $0.1 \% \mathrm{w} / \mathrm{v}$ yeast extract (Difco), $0.01 \%$ $\mathrm{Fe}_{2} \mathrm{SO}_{4}$, and $1.5 \%$ bacto-agar). From plates inoculated with material from each microhabitat, 120 isolated colonies were selected randomly and subcultured until pure. From each set of 120 pure isolates, 96 were chosen randomly to prepare 2 master plates $(6 \times 8=48$ strains each) for replica plating to facilitate testing 
Characterisation of bacterial isolates. Each bacterial strain that grew on the replica plates was sampled from the centre of colonies (i.e. where bacteria were at stationary phase) and classified as follows: morphology: rod, curved rod, or coccoid; and size: $<0.3 \mu \mathrm{m}$, $0.3-0.8 \mu \mathrm{m}, 0.8-1.2 \mu \mathrm{m}, 1.2-3.0 \mu \mathrm{m}, 3.0-5.0 \mu \mathrm{m}$, or $>5.0$ $\mu \mathrm{m}$. In addition, each isolate was tested for 32 other properties, viz. growth at 22,30 , and $37^{\circ} \mathrm{C}$; chromogenicity; motility; fluorescence; ability to hydrolyse agar, alginate, carboxymethylcellulose (CMC), casein, chitin, gelatin, lipids (Tween 80), starch, and urea; growth on thiosulphate-citrate-bile salts (TCBS), and cetramide agar (CET); activity of enzymes $\mathrm{NO}_{2}$ reductase, $\mathrm{NO}_{3}$ reductase, lysine decarboxylase, arginine decarboxylase, ornithine decarboxylase, and tryptophan deaminase (indole test), oxidase, and catalase; acid production from glucose or mannitol under both aerobic and anaerobic conditions (i.e. oxidative/ fermentative tests); fermentation of glucose via pathways indicated by methyl-red test for acid production, and Voges-Proskauer test (VP) for acetoin (an intermediate glucose metabolite); and finally, fermentation of lactose (ONPG test for activity of $\beta$-D-galactoside galactohydrolase).

These characters were used to compare patterns of morphological, physiological, enzymatic and nutritional properties in bacterial populations among microhabitats. No attempt was made to taxonomically identify colonies.

Assays for GABA and L-DOPA. Samples of Clathromorphum sp. collected in July and October 1987, and of Sporolithon sp. collected in July 1987, were analysed for GABA and L-DOPA. Further assays for L-DOPA were conducted on samples of both species collected in October. All samples were collected at $10 \mathrm{~m}$ depth, rinsed thoroughly in SSW and transported in SSW on ice.

Extracts were prepared for the GABA assay by grinding flakes chipped from the algal surface in $0.1 \mathrm{M}$ tetrasodium pyrophosphate buffer $\left(\mathrm{pH} 8.6\right.$ ) at $4{ }^{\circ} \mathrm{C}$ (coralline:buffer $=1: 1$ to $1: 3$ by wt.). Extracts were then halved, and the cells in one half disrupted by sonicating. All extracts were clarified by centrifuging, and sample aliquots of $20 \mu \mathrm{l}$ were assayed for GABA. Analysis for GABA was by the UV-method outlined in the Sigma instruction sheet $5 / 84$ that accompanies the Sigma gabase product (\#G-7509). The method recovers ca $98 \%$ GABA in the range 10 to $40 \mu \mathrm{g}$ per sample.

For L-DOPA assays, crude extracts of coralline algae were prepared in a similar manner, except that grinding was in $0.075 \mathrm{M}$ phosphate buffer, $\mathrm{pH} 7.2$. Aliquots $(0.5 \mathrm{ml})$ were assayed for L-DOPA using the colorimetric method of Arnow (1937). The method is quantitatively accurate in the range 10 to $50 \mu \mathrm{g}$ per $0.5 \mathrm{ml}$ sample. The standard L-DOPA solution $\left(500 \mu \mathrm{g} \mathrm{l}^{-1}\right)$ was prepared from Sigma product \#D-9628. Sample absorbances $\left(A_{510 \mathrm{~nm}}\right)$ were corrected for background colour by subtracting the absorbance of the reaction mix without nitrate molybdate. Since the assay identifies other compounds with phenolic - OH groups, only if the final colour was the intense red/orange characteristic of LDOPA was absorbance taken to indicate the presence of L-DOPA.

If bacteria on the surface of the coralline algal chips produced GABA and/or L-DOPA, it is unlikely that concentrations would be sufficient for detection in assaying coralline chips as just described. Thus, 48 different bacterial phenotypes representative of the range of colony morphologies (all 6 types from Sporolithon sp., 24 from Clathromorphum sp., 6 from the glass slides, and 12 from the seawater samples) were selected and tested for production of GABA and L-DOPA. Samples for assays were prepared from broth cultures of isolates grown at $15^{\circ} \mathrm{C}$ for 2 to $3 \mathrm{~d}$, such that turbidity $\mathrm{A}_{550 \mathrm{~nm}}>1.5$ (broth culture medium was of identical composition to solid growth medium but without the agar). Cells were then harvested, and the supernatant retained to assay for leached or transported GABA and L-DOPA. Harvested cells were washed in $0.25 \mathrm{M}$ phosphate buffer $\left(\mathrm{pH} \mathrm{7.2)}\right.$ at $4{ }^{\circ} \mathrm{C}$, resuspended in cold buffer, and disrupted by sonicating before clearing the extract by centrifuging. Cleared extracts and supernatants were assayed for both GABA (100 $\mu$ l samples) and L-DOPA (250 $\mu$ l samples) using the methods described above.

A subset of 23 phenotypes was assayed for GABA after growing in broth culture containing pyrrolidine conly 23 isolates of a total of 35 survived when grown with pyrrolidine, viz. 5 from Sporolithon sp., 6 from Clathromorphum sp., 4 from the glass slides, and 8 from the seawater samples). This tested for the activity of carboxylation enzymes that catalyse the production of GABA from the precursor pyrrolidine.

Scanning Electron Microscopy (SEM). Bacteria on surfaces of both coralline species were examined by SEM. Samples of Sporolithon sp. and Clathromorphum $\mathrm{sp}$. were collected at the same depths as for bacteriology. Samples were rinsed with SSW and fixed immediately in $2 \%$ glutaraldehyde $(\mathrm{w} / \mathrm{w}$ with sterile artificial seawater) at $4{ }^{\circ} \mathrm{C}$ for at least $36 \mathrm{~h}$. After rinsing in 0.2 $\mu \mathrm{m}$ filtered seawater, samples were then desalinated in a graded salinity series, spending $15 \mathrm{~min}$ each in solutions of $100,75,50,25,0 \%$ and again in $0 \% 0.2 \mu \mathrm{m}$ filtered artificial seawater in glass-distilled water. Dehydration was achieved through a graded alcohol series of $10,30,50,70,90,96$ and $100 \%$ alcohol in glass-distilled water, immersed for 10 to $15 \mathrm{~min}$ per solution. Samples were then critical-point dried, mounted on stubs with a graphite/glue mixture, and coated with gold paladium before viewing. 
Data analysis and statistics. Size frequency distributions, distributions of morphological types, and the frequency of positive scores for each of the other 32 properties examined, were determined for bacterial populations from each of the 5 source microhabitats. Differences among microhabitats in the distribution of morphological types and size-frequencies were tested for significance using $G$-tests on the respective $5 \times 3$ and $5 \times 5$ matrices. If significance was indicated in an overall test, it was followed by an unplanned multiple comparison using $G$-tests in a simultaneous test procedure (Sokal \& Rohlf 1981). Similarly, for each of the 32 (binary) characters, differences among microhabitats in the frequency of isolates exhibiting a given trait were examined by $G$-tests on each $5 \times 2$ matrix, and followed by simultaneous $G$-tests if significance was indicated in overall tests. In the overall tests, the William's correction to $G$ was applied (Sokal \& Rohlf 1981), and for the binary data $(5 \times 2$ matrices) the Bonferroni adjustment was made to the nominal rate of Type 1 error such that the significance level was $\alpha=0.05 / 32=$ 0.0016, which provided conservative tests. G-tests were performed using the BIOM statistical software package (Rohlf 1982).

Multivariate analyses were conducted to examine relationships among the 5 microhabitats based on properties of the bacterial strains isolated from them. A $5 \times 5$ dissimilarity matrix of Bray-Curtis coefficients (see Bray \& Curtis 1957. Field et al. 1982) was constructed from the untransformed $5 \times 32$ data matrix that summarised, for each of the 32 characters, the proportion of strains from each microhabitat that demonstrated a given property. Relationships among microhabitats were examined by (1) a hybrid (sensu Faith et al. 1987) nonmetric multidimensional scaling routine (MDS) in which 30 different initial random

Table 1. Summary of survival of 96 colonies originally isolated from each habitat, and uniqueness of phenotypic strains within and among microhabitats (SW1. SW2: seawater samples; GS: glass slide; SPO: Sporolithon sp.; CLA: Clathromorphum). Total colonies is number that survived to enable completion of all tests. Percentages in parentheses are of total number of colonies and ${ }^{b}$ total number of phenotypes within habitat

\begin{tabular}{|lccc|}
\hline Habitat & $\begin{array}{c}\text { Total } \\
\text { colonies }\end{array}$ & $\begin{array}{c}\text { Total no. } \\
\text { phenotypes } \\
\text { within habitat } \\
(\%)^{\mathrm{a}}\end{array}$ & $\begin{array}{c}\text { Total no. } \\
\text { phenotypes } \\
\text { unique to } \\
\text { habitat }(\%)^{\circ}\end{array}$ \\
\hline SW1 & 49 & $48(98.0)$ & $45(93.8)$ \\
SW2 & 55 & $50(90.9)$ & $47(94.0)$ \\
GS & 78 & $70(89.7)$ & $69(98.6)$ \\
SPO & 96 & $6(6.3)$ & $6(100)$ \\
CLA & 81 & $65(80.2)$ & $62(95.4)$ \\
\hline
\end{tabular}

configurations were used to ensure that a global minimum stress was attained, and (2) by cluster analyses using several moderate to strongly clustering sorting strategies, viz. 'flexible' strategy with cluster intensity coefficient $\beta=-0.25$, furthest neighbour, groupaverage with $\beta=-0.25$, flexible weighted pair-group with $\beta=-0.25$, and weighted-centroid or median; see Clifford \& Stephenson (1975) and Williams (1976). Multivariate analyses were conducted using the PATN pattern analysis package (Belbin 1987; the version of the MDS routine was the 1989 update, which is a development of the Bell Laboratories KYST program of J. B. Kruskal and others).

\section{RESULTS}

\section{Properties of plate-viable bacteria and characterisation of microhabitats}

Within microhabitats, most isolates differed from one another in at least one of the 34 characters, i.e. they were different phenotypic strains (Table 1). The exception was Sporolithon sp. which demonstrated a much lower diversity of phenotypes; 91 of the 96 colonies were identical, although none of the 6 different strains from this coralline were identified from any other microhabitat (Table 1). Similarly for each of the other microhabitats, a high percentage of phenotypes isolated were unique to that particular habitat (Table 1).

Distributions of morphologies and size-frequencies. The relative abundances of bacterial morphologies varied significantly among microhabitats (Fig. 1). Most bacteria isolated from surfaces of Sporolithon sp. and Clathromorphum $\mathrm{sp}$. and from seawater were rods, but there were more curved rods in samples from seawater than from the corallines. In contrast, populations from the glass slides were dominated by curved rods, and rods accounted for only $37 \%$ of strains. Cocci were poorly represented in all samples.

The distribution of size-frequencies of bacteria grown on plates also differed significantly among microhabitats (Fig. 2). Because most of the colonies isolated from Sporolithon sp. were ostensibly the same taxon, it was not surprising that most isolates from this source were of a single size class $(1.2$ to $3.0 \mu \mathrm{m})$. The range of sizes isolated from Clathromorphum sp. was much greater, reflecting a greater number of phenotypes, and this was the only habitat in which microbes $<0.3 \mu \mathrm{m}$ were well represented. The distribution of size classes from the 2 corallines differed significantly from each other as well as from populations from all other microhabitats. Patterns of size frequency among the seawater samples and glass slides did not differ significantly, and most bacteria from these habitats 
Fig. 1 Frequency of morphological types in populations of bacteria isolated from the 5 microhabitats. The distribution of morphologies was dependent on habitat $\left(G_{a d j}=96.79\right.$, to be compared with critical $\chi_{a=0.05(8)}^{2}=15.51$ ). The distribution from the glass slides was significantly different to that from other microhabitats, but differences among coralline and seawater habitats were not significant. R: rod; CR: curved rod; $\mathrm{C}$ : coccus

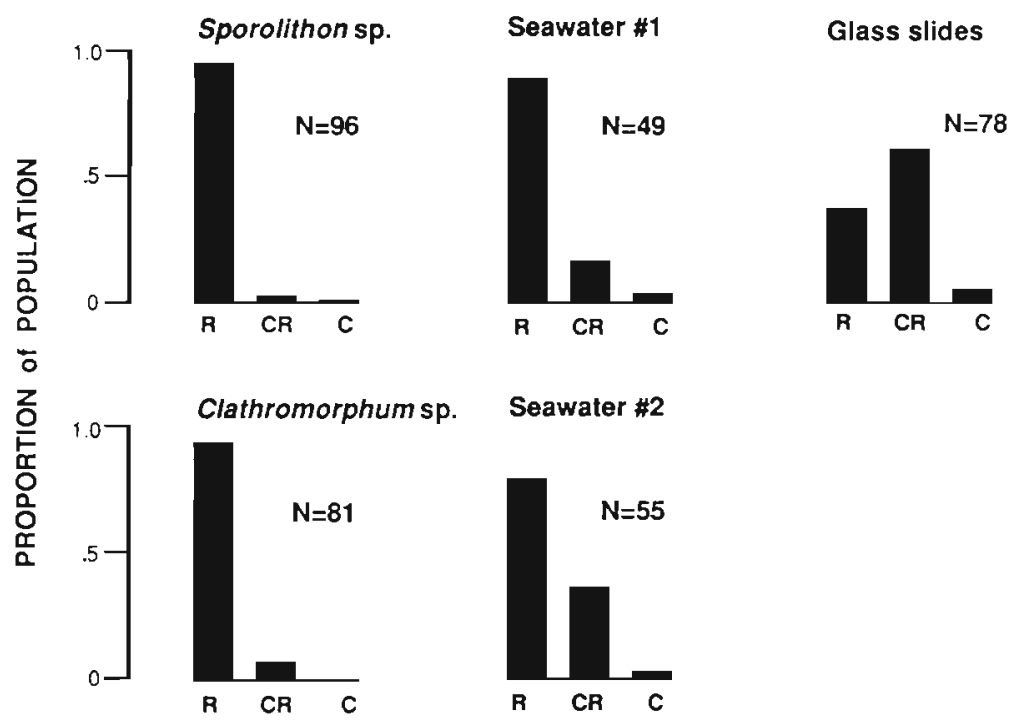

alcohol mannitol, either aerobically or anaerobically, and (4) were unable to utilize glucose, either aerobically, anaerobically or via fermentative pathways. Similarly, most of these bacteria were unable to utilise common amino acids or other simple nitrogenous compounds since they did not demonstrate activity of the enzymes arginine-, lysine- and ornithine-decarboxylase, tryptophan-deaminase, $\mathrm{NO}_{2}$ - and $\mathrm{NO}_{3}$-reductase; nor could they hydrolyse the simple nitrogenous compound urea. Interestingly, the abundant chromogenic isolate (probably Flavobacterium) from Sporolithon sp. could hydrolyse only lipids and complex proteins lose chiti

Sporolithon sp.

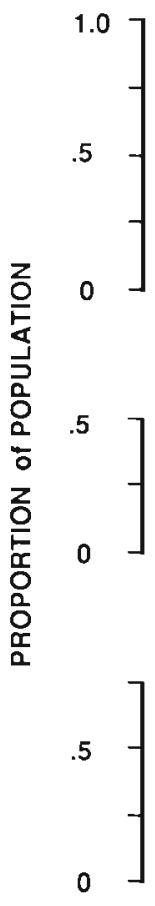

Seawater \#1

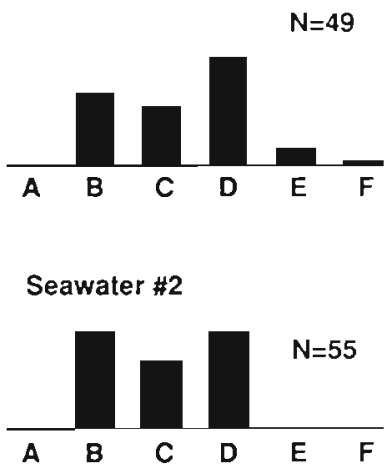

Fig. 2. Size-frequency distributions of bacterial populations isolated from 5 microhabitats. Dependence of distributions on habitat was indicated $\left(G_{a d j}=154.28\right.$, to be compared with critical $\chi_{n=0.05|20|}^{2}=31.41$, and multiple contrasts identified 3 significantly different subsets; distributions of Sporolithon sp. and Clathromorphum sp. differed significantly from each other and from all other microhabitats, but differences among size-frequency patterns of bacteria 1solated from the glass slides and 2 seawater samples were not significant. Key to size classes: $\mathrm{A}=<0.3 \mu \mathrm{m} ; \mathrm{B}=0.3-0.8 \mu \mathrm{m} ; \mathrm{C}=$ $0.8-1.2 \mu \mathrm{m} ; \mathrm{D}=1.2-3.0 \mu \mathrm{m} ; \mathrm{E}=3.0-5.0 \mu \mathrm{m}$; $\mathrm{F}=>5.0 \mu \mathrm{m}$

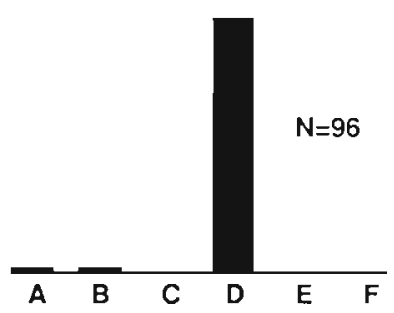

Clathromorphum sp.

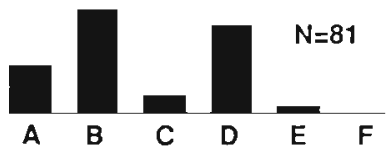

Glass slides

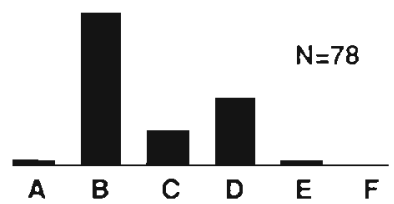


Table 2. Summary of properties of bacterial populations from the 5 microhabitats (microhabitat abbreviations as for Table 1). Data are proportions of populations exhibiting trait, and results of $G$-tests for independence of frequency of traits among habitats. $\left(G_{\text {adt }}\right.$ is value of $G$ after Williams correction; ${ }^{*}$ indicates significance determined by comparing $G_{\text {adj }}$ with a critical value of $\chi^{2}=17.48$, $\mathrm{df}=4$, Bonferroni adjusted $\alpha=0.05 / 32=0.0016$ \}

\begin{tabular}{|c|c|c|c|c|c|c|}
\hline Property & SW1 & SW2 & $\begin{array}{c}\text { Habitat } \\
\text { GS }\end{array}$ & $\mathrm{SPO}$ & CLA & $G_{\mathrm{add}}$ \\
\hline $\mathrm{N}$ (total number of isolates) & 49 & 55 & 78 & 96 & 81 & \\
\hline $\begin{array}{l}\text { Growth at } 22^{\circ} \mathrm{C} \\
\text { Growth at } 30^{\circ} \mathrm{C} \\
\text { Growth at } 37^{\circ} \mathrm{C} \\
\text { Chromogenicity } \\
\text { Motility } \\
\text { Fluorescence }\end{array}$ & $\begin{array}{l}.959 \\
.633 \\
.429 \\
.286 \\
.633 \\
.000\end{array}$ & $\begin{array}{l}1.000 \\
.455 \\
.327 \\
.309 \\
.418 \\
.000\end{array}$ & $\begin{array}{l}1.000 \\
.756 \\
.256 \\
.026 \\
.000 \\
.000\end{array}$ & $\begin{array}{r}1.000 \\
.010 \\
.010 \\
.958 \\
.000 \\
.000\end{array}$ & $\begin{array}{l}.827 \\
.012 \\
.000 \\
.506 \\
.395 \\
.000\end{array}$ & $\begin{array}{r}\cdot 37.05 \\
\cdot 202.36 \\
\cdot 86.06 \\
\cdot 203.03 \\
\cdot 125.87 \\
0.00\end{array}$ \\
\hline $\begin{array}{l}\text { Hydrolysis of: } \\
\text { Agar } \\
\text { Alginate } \\
\text { Casein } \\
\text { Chitin } \\
\text { CMC } \\
\text { Gelatin } \\
\text { Lipid } \\
\text { Starch } \\
\text { Urea }\end{array}$ & $\begin{array}{l}.000 \\
.000 \\
.347 \\
.163 \\
.041 \\
.449 \\
.408 \\
.327 \\
.020\end{array}$ & $\begin{array}{l}109 \\
.000 \\
.218 \\
109 \\
.073 \\
.636 \\
182 \\
.109 \\
.018\end{array}$ & $\begin{array}{r}.295 \\
103 \\
.295 \\
.000 \\
.026 \\
1.000 \\
.564 \\
.256 \\
.038\end{array}$ & $\begin{array}{l}.010 \\
.010 \\
.969 \\
.010 \\
.010 \\
.969 \\
.969 \\
.031 \\
.000\end{array}$ & $\begin{array}{l}.000 \\
.012 \\
.074 \\
.000 \\
.000 \\
.309 \\
.358 \\
.000 \\
.025\end{array}$ & $\begin{array}{r}\cdot 60.54 \\
16.13 \\
\cdot 201.68 \\
\cdot 29.85 \\
8.06 \\
\cdot 167.45 \\
\cdot 135.78 \\
\cdot 54.37 \\
4.37\end{array}$ \\
\hline $\begin{array}{l}\text { CET test } \\
\text { TCBS test } \\
\text { Indole test }\end{array}$ & $\begin{array}{r}.082 \\
184 \\
.082\end{array}$ & $\begin{array}{l}.000 \\
.200 \\
.000\end{array}$ & $\begin{array}{l}128 \\
.051 \\
.000\end{array}$ & $\begin{array}{l}.042 \\
.042 \\
.000\end{array}$ & $\begin{array}{l}.000 \\
.000 \\
.012\end{array}$ & $\begin{array}{r}\cdot 20.88 \\
\cdot 28.92 \\
11.69\end{array}$ \\
\hline $\begin{array}{l}\text { Activity of: } \\
\text { Arginine decarboxylase } \\
\text { Lysine decarboxylase } \\
\text { Ornithine decarboxylase } \\
\mathrm{NO}_{3} \text {-reductase } \\
\mathrm{NO}_{2} \text {-reductase } \\
\text { Oxidase } \\
\text { Catalase }\end{array}$ & $\begin{array}{l}.224 \\
.041 \\
.020 \\
.204 \\
.082 \\
.592 \\
.367\end{array}$ & $\begin{array}{l}.091 \\
.000 \\
.018 \\
164 \\
.000 \\
.618 \\
.455\end{array}$ & $\begin{array}{l}.026 \\
.000 \\
.000 \\
.218 \\
.000 \\
718 \\
.372\end{array}$ & $\begin{array}{l}.000 \\
.000 \\
.000 \\
.000 \\
.000 \\
.052 \\
.000\end{array}$ & $\begin{array}{l}.000 \\
.000 \\
.000 \\
.086 \\
.000 \\
.852 \\
148\end{array}$ & $\begin{array}{r}\cdot 36.36 \\
5.24 \\
3.25 \\
\cdot 34.21 \\
12.80 \\
\cdot 154.80 \\
\cdot 78.43\end{array}$ \\
\hline $\begin{array}{l}\text { Acid production from: } \\
\text { Mannitol (aerobic) } \\
\text { Glucose (aerobic) } \\
\text { Mannitol (anaerobic) } \\
\text { Glucose (anaerobic) }\end{array}$ & $\begin{array}{l}.286 \\
.449 \\
.286 \\
.429\end{array}$ & $\begin{array}{l}.255 \\
.309 \\
.273 \\
.382\end{array}$ & $\begin{array}{l}.603 \\
.321 \\
141 \\
.615\end{array}$ & $\begin{array}{l}.010 \\
.042 \\
.010 \\
.021\end{array}$ & $\begin{array}{l}.012 \\
.049 \\
.012 \\
.037\end{array}$ & $\begin{array}{r}\cdot 123.68 \\
\cdot 60.49 \\
\cdot 49.40 \\
\cdot 124.24\end{array}$ \\
\hline $\begin{array}{l}\text { Methyl red test } \\
\text { ONPG test } \\
\text { VP test }\end{array}$ & $\begin{array}{l}.224 \\
122 \\
.000\end{array}$ & $\begin{array}{l}.218 \\
145 \\
.000\end{array}$ & $\begin{array}{l}.590 \\
.667 \\
.000\end{array}$ & $\begin{array}{l}.000 \\
.031 \\
.010\end{array}$ & $\begin{array}{l}.037 \\
.000 \\
.012\end{array}$ & $\begin{array}{r}\cdot 116.86 \\
\cdot 141.05 \\
1.86\end{array}$ \\
\hline
\end{tabular}

(casein and gelatin). These characteristics suggest strongly that a proportion of plate-viable bacteria from Clathromorphum sp. and Sporolithon sp. are highly specialised in their nutritional requirements.

Among microhabitats, significant differences in the proportion of isolates manifesting a given trait were demonstrated in all but 9 characters, even after following the conservative statistical procedure of adjusting significance levels by the Bonferroni method (Table 2 , Fig. 3). These data highlight that many of the population trends were microhabitat-specific, and indicate further that coralline bacteria are more specialised than their counterparts occurring in seawater and growing on hard, but biologically inert, surfaces. Relative to coralline bacteria, a greater proportion of microbes from seawater and glass slides (1) grew at $30^{\circ}$ and $37^{\circ} \mathrm{C}$, (2) could hydrolyze starch and CMC, (3) demonstrated activity of arginine decarboxylase, $\mathrm{NO}_{3}$ reductase, and catalase enzymes, (4) were able to utilize mannitol and glucose aerobically and anaerobically, and (5) indicated ability to ferment both lactose (ONPG test) and glucose (methyl red test); most of these differences were statistically significant. Bacteria from the glass slides differed from other populations in that fewer were chromogenic, but a greater proportion hydrolyzed agar and alginate, and grew on cetramide agar. The seawater microbes were distinct in that a greater proportion of isolates manifested activity of ornithine 


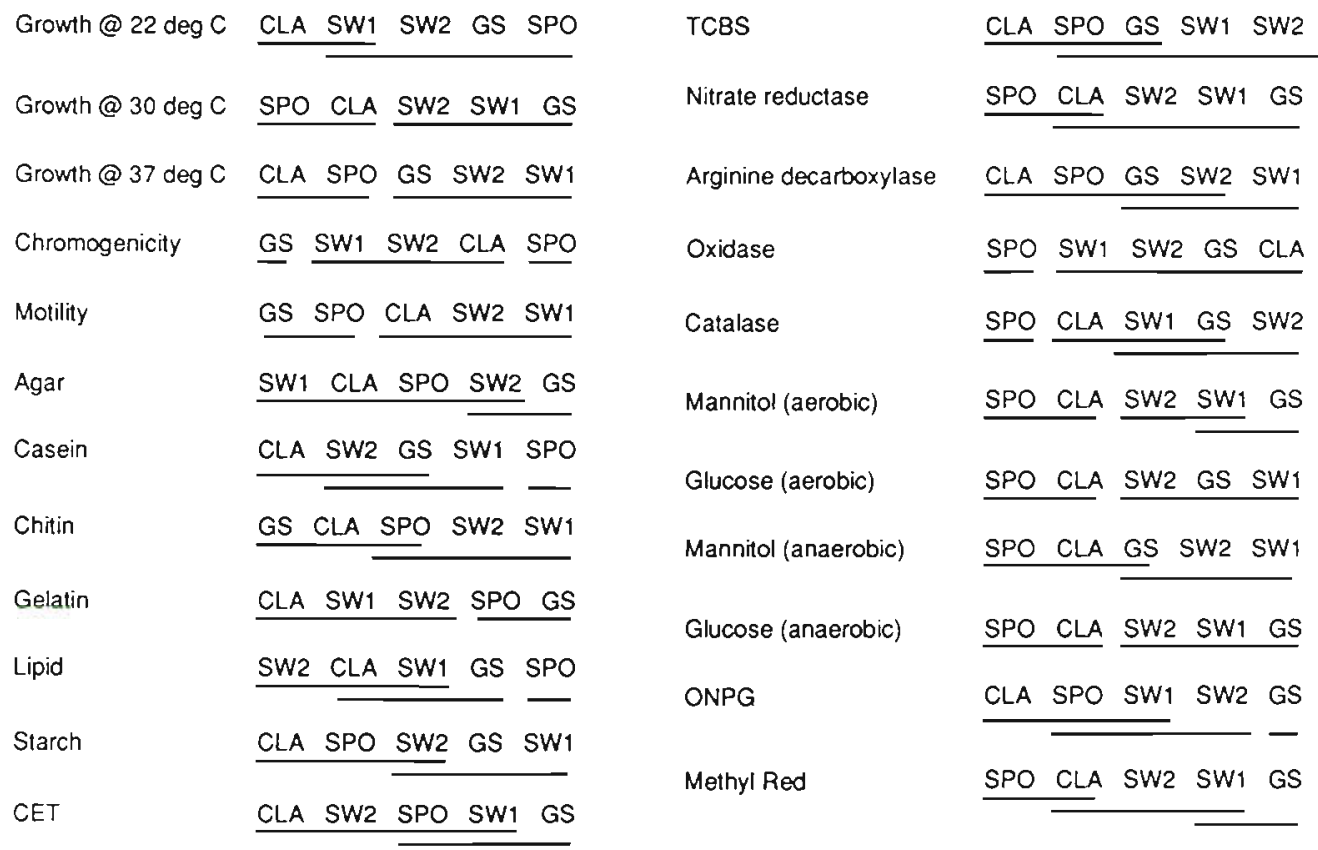

Fig. 3. Nature of differences in properties of bacteria among microhabitats indicated by results of simultaneous contrast procedures (Williams-adjusted G-tests) on characters exhibiting significantly different proportions among microhabitats (see Table 2). Solid bars identify homogeneous (= nonsignificant) subsets. Microhabitats are presented left-to-right in ascending order of proportion of population exhibiting trait. CLA: Clathromorphum sp.; SPO: Sporolithon sp.; GS: glass slide; SW1 and SW2: seawater samples

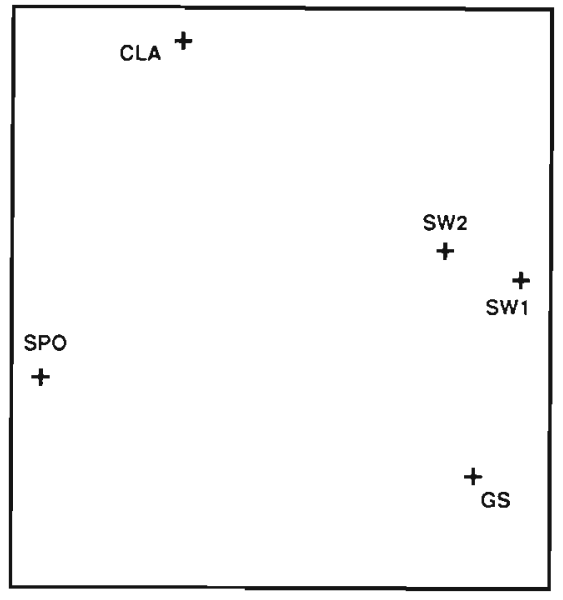

Fig. 4. Ordination of the 5 microhabitats in 2 dimensions using multidimensional scaling on matrix of Bray-Curtis coefficients (matrix derived from 32 physiological, nutritional and other characters of bacteria; minimum stress attained $=0.047$ ) Abbreviations for microhabitats as in Fig. 3. Axis scales are arbitrary

decarboxylase, hydrolyzed chitin, and grew on thiosulphate-citrate-bile salts. Again, most of these differences were statistically significant. Notably, none of the differences in characteristics of isolates from the 2 seawater samples were significant. In contrast, several characteristics differed significantly among the 2 coral- line species, viz. a greater proportion of colonies isolated from Sporolithon sp. (1) grew at $22^{\circ} \mathrm{C}$, (2) were chromogenic, and (3) could hydrolyze casein, gelatin and lipids, whereas significantly more isolates from Clathromorphum sp. (1) were motile, and (2) demonstrated activity of oxidase and catalase enzymes.

Multivariate analyses. Relationships among the 5 bacterial populations indicated by results of multidimensional scaling (Fig. 4) and several cluster analyses (Fig. 5) were qualitatively identical, and confirmed the trend evident from comparisons among individual characters. There was a close similarity in the plate-viable bacterial populations from the 2 seawater samples, with the glass slide population being more similar to the seawater samples than to microbes isolated from the corallines. Bacteria from the 2 corallines were dissimilar, but more similar to each other than to populations from any of the other microhabitats.

\section{Distribution of bacteria on surfaces of coralline algae}

Examination of several plants of both species of coralline algae by scanning electron microscopy revealed that the abundances and distributions of bacteria on their surfaces were dissimilar. Rod-shaped and chain-forming bacteria were more evident on Clathromorphum sp. than on Sporolithon sp., and 


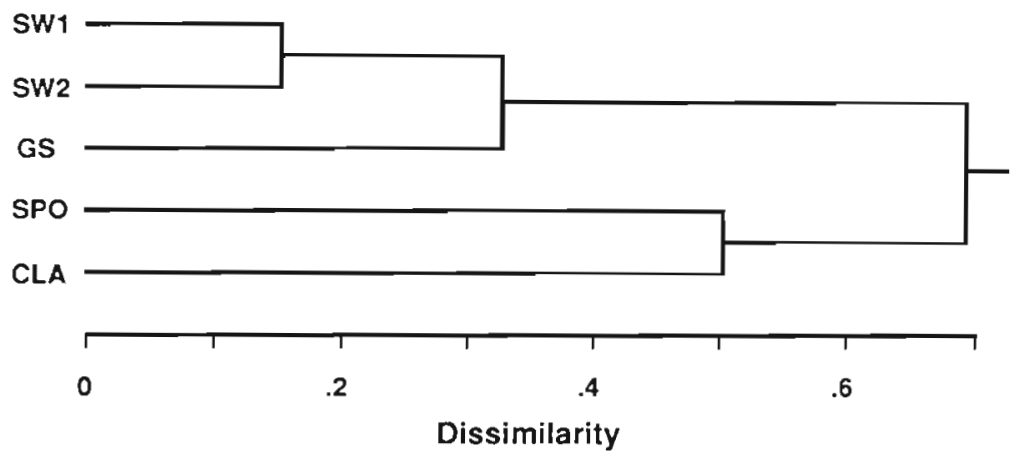

Fig. 5. Classification of the 5 mucrohabitats using cluster analysis based on same dissimilarity matrix used in ordination procedure (see Fig. 4). Dendrogram shown is for group average sorting strategy with cluster intensity coefficent $\beta=$ -0.25 . Dendrograms from all other sorting strategies were qualitatively identical to the one shown. Abbreviations for microhabitats as in Fig. 3

diatoms were observed only on Clathromorphum sp. On surfaces of Sporolithon sp., bacteria were not distributed uniformly; they grew abundantly from within cavities of coralline cells with damaged end-walls, but occurred rarely on exposed ends of calcified vertical cell walls, even though these bare calcified parts provided a relatively large area for attachment (Fig. 6a). Bacteria were often observed growing from within ruptured plasmalemmae (Fig. 6b). Old sections of thallus showing no evidence of recent damage were largely free of bacterial colonisation, but occasional clusters of a Flectobacillus-like (= Microcyclus) microbe (see Sieburth et al. 1975, Raj 1981) were evident (Fig. 6c). In contrast, areas of crust that were obviously damaged were colonised heavily, and the boundaries of damaged/non-damaged regions were readily identified by different densities of bacteria (Fig. 6d, e). This pattern of colonisation was observed on grazing scars. Evidence of primary pit connections on all intact end-cell walls (Fig. 6c, e) suggests that, like most crustose corallines (see Johnson \& Mann 1986), Sporolithon sp. sloughs epithallial cells regularly. However, sloughing of sheets of cells, as was observed in Clathromorphum sp., or scales (Johnson \& Mann 1986), was not observed.

Surfaces of Clathromorphum sp. were distinguished by 2 prominent features; the crust was always fouled heavily by bacteria and micro-algae, and surface cells were sloughed off in sheets (Fig. 6f, g). Bacteria were numerous even on newly-exposed surfaces beneath lifting sections of thallus (Fig. 6h, i), although the degree of colonisation on these areas was less than on older exposed surfaces (cf. Fig. 6f to i). This suggests that sloughing in Clathromorphum sp. may expose coralline-derived compounds for bacterial growth. The mucus-like matrix that covers cells of Clathromorphum $\mathrm{sp}$. (Fig. 6h, i) may be the source of nutritional compounds. Because of the presence of this mucus-like covering, unlike Sporolithon sp., exposed calcified cell walls were not observed.

\section{Production of GABA and L-DOPA by corallines and bacteria}

Neither GABA nor L-DOPA were detected in either sonicated or non-sonicated cell-free extracts of either Sporolithon sp. or Clathromorphum sp., or from growth medium supernatants or cell-free extracts of bacteria isolated from all 5 microhabitats (Table 3). Similarly, GABA was not detected in supernatants or cell-free extracts of bacteria grown with pyrrolidine, indicating absence of activity or carboxylation enzymes to catalyse production of GABA from pyrrolidine. Since assays conducted with standard solutions confirmed that low concentrations of these compounds could be detected by the procedures followed (see 'Methods' for ranges), these results indicate that free GABA and L-DOPA are not produced by these CCA or their associated surface bacteria, nor by bacteria isolated from seawater or artificial substrata within the ecological habitat of these algae.

Fig. 6. Electron micrographs of bacteria on surfaces of coralline algae. On Sporolithon sp., bacteria often grew from within cavities of cells with damaged end-walls, but were much less abundant on the exposed ends of vertical walls (a). Bacter.a were readily observed protruding from broken plasmalemmae (b), but areas of old undamaged crust were largely devoid of microbes (c) except for occasional groups of Flectobacillus-like (= Microcyclus) bacteria. Heavy bacterial fouling occurred only on areas of damaged crust, and stopped abruptly at boundaries of damaged/undamaged areas (d, e). Sporolithon sp. apparently sloughs epithallial cells regularly, as all intact cells showed primary pit connections $(c, e)$. Surfaces of Clathromorphum sp. revealed a different pattern and were distinguished by uniformly dense colonisation by bacteria and microalgae and sloughing of surface cells in sheets (f, g). Even beneath newly lifted sheets, bacterial colonisation appeared rapid (h, i). Note mucus-like cuticle/matrix covering Clathromorphum sp. cells $(\mathrm{h}, \mathrm{i})$, and that rod and chainforming bacteria were more common on Clathromorphum sp. [cf. (a) to (e) vs (f) to (i) ). Scale bars are $5 \mu \mathrm{m}$ in (b), $10 \mu \mathrm{m}$ in (a), (c), (d), (e), (h), (i), $50 \mu \mathrm{m}$ in (g), and $200 \mu \mathrm{m}$ in (f); $\mathrm{p}=$ primary pit connection 

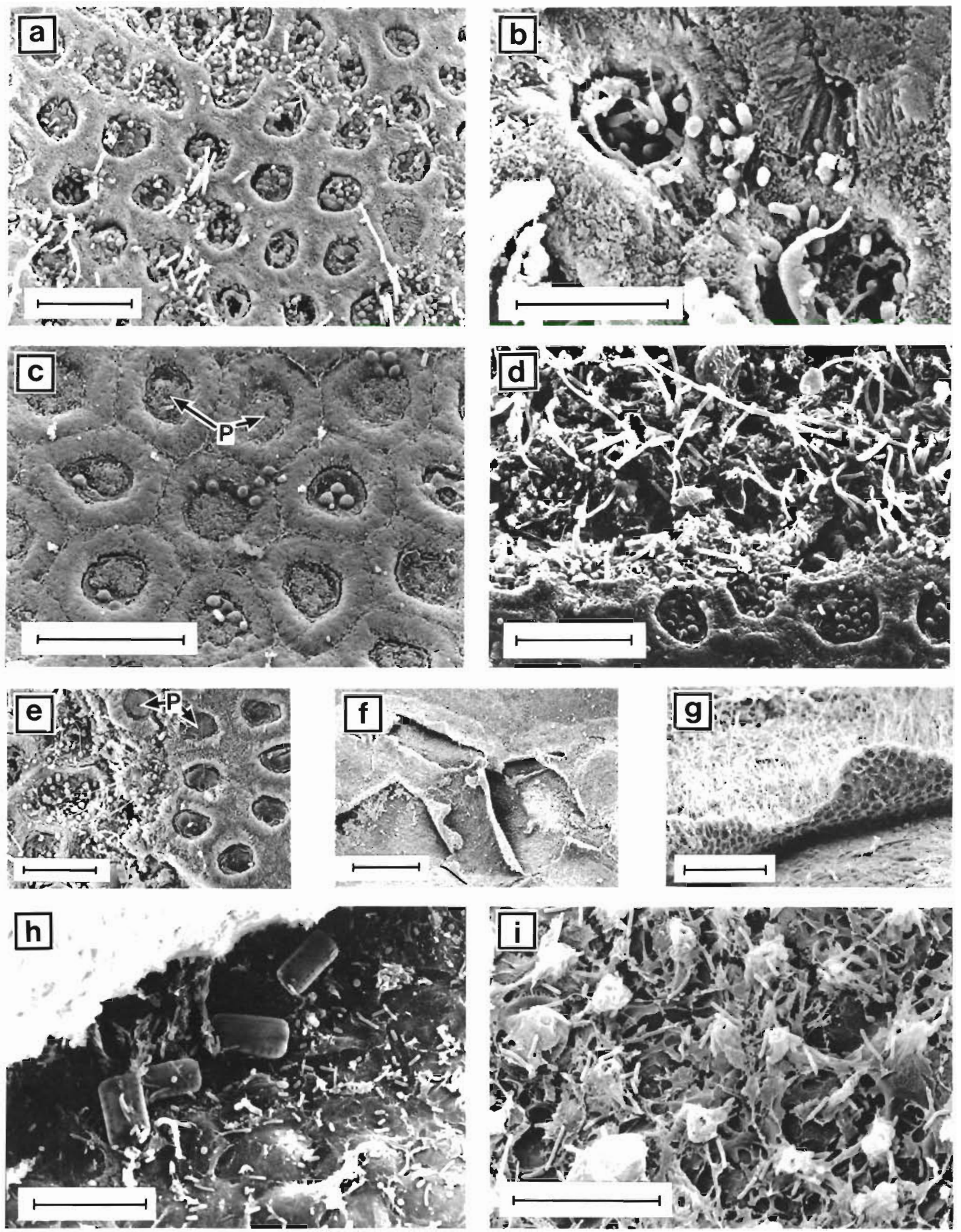
Table 3. Results of assays for GABA and L-DOPA in cell-free extracts and supernatants (bacteria only) prepared from (1) 2 species of crustose coralline algae, (2) 48 bacterial phenotypes isolated from both coralline species, seawater ( 2 samples) and glass slides, and (3) 23 bacterial isolates from the same $5 \mathrm{mi}$ crohabitats, but grown with pyrrolidine. -- indicates no assay attempted. Percentages are of total number of different bacterial taxa isolated from given microhabitat

\begin{tabular}{|c|c|c|}
\hline Source & $\begin{array}{c}\text { GABA } \\
\text { (ug ml } \mathrm{ml}^{-1} \\
\text { sample) }\end{array}$ & $\begin{array}{l}\text { L-DOPA } \\
\text { (1/g } \mathrm{ml}^{-1} \\
\text { sample) }\end{array}$ \\
\hline \multicolumn{3}{|l|}{ Corallines } \\
\hline \multicolumn{3}{|l|}{ Sporolithon sp. } \\
\hline 7 Jul (2 plants) & 0 & 0 \\
\hline 7 Oct (1 plant) & - & 0 \\
\hline \multicolumn{3}{|l|}{ Clathromorphum sp. } \\
\hline 7 Jul (2 plants) & 0 & 0 \\
\hline 2 Oct ( 2 plants $)$ & 0 & 0 \\
\hline 7 Oct (1 plant) & - & 0 \\
\hline \multicolumn{3}{|l|}{ Bacteria } \\
\hline $\begin{array}{l}\text { From Sporolithon sp. } \\
\qquad(6 \text { taxa }=100 \% \text { of total })\end{array}$ & 0 & 0 \\
\hline $\begin{array}{l}\text { From Clathromorphum sp. } \\
\quad(24 \text { taxa }=36.9 \% \text { of total) } \\
\text { From glass slide }\end{array}$ & 0 & 0 \\
\hline $\begin{array}{l}\text { ( } 6 \text { taxa }=8.6 \% \text { of total) } \\
\text { From seawater }\end{array}$ & 0 & 0 \\
\hline$(12 \operatorname{taxa}=13.3 \%$ of total $)$ & 0 & 0 \\
\hline \multicolumn{3}{|l|}{ Bacteria grown with pyrrolidine } \\
\hline $\begin{array}{l}\text { From Sporolithon sp. } \\
\qquad(5 \text { taxa }=83.3 \% \text { of total })\end{array}$ & 0 & -- \\
\hline $\begin{array}{l}\text { From Clathromorphum sp. } \\
\qquad(6 \text { taxa }=9.2 \% \text { of total })\end{array}$ & 0 & - \\
\hline $\begin{array}{l}\text { From glass slide } \\
\qquad(4 \operatorname{tax} \mathrm{a}=5.7 \% \text { of total })\end{array}$ & 0 & - \\
\hline $\begin{array}{l}\text { From seawater } \\
\qquad(8 \text { taxa }=8.9 \% \text { of total })\end{array}$ & 0 & - \\
\hline
\end{tabular}

\section{DISCUSSION}

\section{Bacteria from coralline surfaces are distinctive}

If the hypothesis of bacterial origin of CCA-associated inducers of some marine invertebrate larvae is correct, then bacterial populations on corallines must be distinct from those growing on other marine surfaces. Since all marine substrata support bacteria, this condition is necessary to account for the moderate to high degree of substratum specificity for CCA demonstrated by larvae of several species in laboratory studies (soft octocoral, Sebens 1983a; scleractinian coral, Morse et al. 1988; polychaete, Gee 1965; chiton. Barnes \& Gonor 1973, Rumrill \& Cameron 1983; abalone, Morse et al. 1979, Morse \& Morse 1984a, Morse 1985; asteroid, Barker 1977, Johnson et al. 1991 ) and in the recruitment of juveniles in the field (soft octocoral, Sebens 1983b; abalone, Saito 1981. Shepherd \& Turner 1985, Prince et al. 1987. McShane \& Smith 1988).

Although plate-viable bacteria will comprise a small proportion of bacterial populations from marine microhabitats (cf. Kaneko et al. 1978, Davis et al. 1983, Hobbie 1988), an indication of differences among populations can be ascertained by comparing properties of plate-viable isolates. Thus, our results provide evidence that bacterial populations from coralline crusts are characteristic, and distinct from those isolated from different neighbouring microhabitats. This suggests that some bacteria associated with coralline surfaces occur rarely in other marine microhabitats. Lewis et al. (1985) reached similar conclusions after finding that Moraxella spp. occurred abundantly among plate-viable bacteria obtained from coralline crusts in Tasmania, but occurred rarely among isolates from seawater. We have no reason to suppose that the clear distinctions among coralline and non-coralline bacteria, as evident among plate-viable isolates, would not occur among non-plateable bacteria as well.

\section{Relationship between bacteria and corallines}

Differences in bacterial populations among different marine microhabitats have been attributed to contrasting physical (e.g. temperature) and especially nutritional and substrate (i.e. chemical and biological) properties among habitats (Kaneko et al. 1978, Davis et al. 1983). Similarly, our evidence of the distinctiveness of coralline-associated bacteria, their nutritional requirements, and their distribution on crust surfaces suggests that coralline crusts provide a unique nutritional environment for certain epiphytic bacteria. Moreover, some strains may be specialised to utilise resources peculiar to this microhabitat.

Several lines of evidence support this argument. If the crust surface simply provided a biologically/chemically inert hard surface for attachment, it could be expected that (1) bacteria on corallines would be similar to those that grew on glass slides adjacent to the corallines $(<2$ to $5 \mathrm{~cm}$ away), and (2) that they would grow on the crust wherever there was a hard surface for attachment. Neither of these was the case. First, multivariate procedures indicated that bacteria from glass substrata were more similar to those isolated from seawater samples than to CCA bacteria. Differences among water column and glass slide populations might be attributed to the inability of some water-borne bacteria to attach to hard surfaces. Second, bacteria were not abundant on hard surfaces of the crust which appeared to offer a suitable surface for attachment. Bacteria were highly clumped on the surface of 
Sporolithon sp., being most dense within concavities of damaged cells, but occurring sparsely on exposed calcified cell walls that comprised most of the area of the crust surface. Although Clathromorphum sp. was colonised more densely and bacteria were abundant on all areas of crust, the surface of this species was covered with a mucilage-like matrix, and calcareous walls were not exposed. Micrographs from other studies show a similar pattern, bacteria being most abundant within concavities of damaged cells in plants which show bare calcified walls (Garland et al. 1985, Johnson \& Mann 1986), but distributed continuously on surfaces with an intact mucilaginous cuticle (Lewis et al. 1985).

These distribution patterns suggest strongly that bacteria utilise compounds derived from the alga, either from damaged surface cells or from the mucilage-like matrix. Moreover, our results indicate that some strains may be specialised in exploiting this source of nutrients. A large proportion of bacteria isolated from both CCA species gave negative results in many tests. Of particular significance is that most were unable to either utilise glucose or hydrolyse complex carbohydrates, and were unable to utilise simple amino acids, or reduce nitrate, or hydrolyse urea. The dominant phenotype from Sporolithon sp. could utilise only lipids and complex proteins. These results suggest specialised nutritional requirements, such that growth (but not necessarily survival) of bacteria depends on the coralline to provide particular substrates. Since bacteria from the 2 coralline species were dissimilar, it is likely that available substrates for growth from within damaged surface cells are different from those available in the mucus-like matrix on which most bacteria from Clathromorphum sp. were observed. A further indication of specialisation is that the temperature range for growth was much narrower for bacteria isolated from the algae than for microbes from other microhabitats.

Our overall conclusion is that several plate-viable bacteria on coralline crusts are specifically and characteristically associated with the alga, and that they may require the coralline to supply specific compounds for their growth. The nature of the association may be species-specific for some strains, and depend in large part on the source of coralline-derived compounds, e.g. damaged cells versus surface mucus. Without evidence to the contrary, it may be reasonable to extrapolate and extend this conclusion to include non-plateable bacteria.

\section{Competing hypotheses of origin of inducers associated with $\mathrm{CCA}$}

Two alternative hypotheses of the source of inducers associated with CCA are that they are (1) algal or (2) bacterial in origin. In the example of induction of Haliotis rufescens (see 'Introduction'), it has been suggested that CCA-associated inducers are algal in origin (Morse \& Morse 1984a, Morse et al. 1984, Morse 1985). However, since bacteria occur abundantly on the surfaces of coralline algae (Garbary \& Veltkamp 1980, Garland et al. 1985, Lewis et al. 1985, Johnson \& Mann 1986, Johnson et al. 1991, this study), the cell-free extracts of CCA from which Morse and co-workers purified and characterized morphogens would contain water-soluble compounds from both epiphytic bacteria and the alga. Although laboratory bioassays have indicated that $H$. rufescens larvae are not induced by the bacterium Escherichia coli, or by intact marine bacteria isolated from seawater or from non-biological substrata from their natural habitat (see Morse et al. 1979, 1980, 1984), induction of Haliotis larvae by plates fouled with bacteria and microalgae is the most widely used method in commercial hatcheries (Hahn 1989 and references cited therein). If bacteria do play a role in induction of Haliotis, the apparently characteristic bacterial biota associated with coralline crusts may explain why some bioassays conducted with non-coralline marine bacteria have failed to demonstrate morphogenic activity. It is noteworthy that inducers of $H$. rufescens can be removed by lightly brushing the coralline surface (Morse \& Morse 1984a), which is consistent with the hypothesis that surface bacteria may be the source of inducers.

The results of the present study are consistent with the possibility of bacterial origin of CCA-associated inducers. Several published observations also recommend the idea as worthy of further investigation. Bacteria or their products are known to enhance rates of settlement and metamorphosis of many marine invertebrate larvae (scyphozoans, Hofmann et al. 1978, Neumann 1979, Fitt et al. 1987, Hofmann \& Brand 1987; polychaetes, Gray 1966, 1967, Kirchman et al. 1982; abalone, Hahn et al. 1989; oysters, Weiner et al. 1985, Fitt et al. 1989; bryozoans, Mihm et al. 1981, Brancato \& Woollacott 1982; sea urchins, Cameron \& Hinegardner 1974), and in several of these examples, specific strains or bacterially-produced compounds have been identified. Regarding bacteria associated with CCA in particular, epiphytic bacteria on the CCA Lithothamnium pseudosorum have been implicated in the enhancement of settlement rates of larvae of crown-of-thorns starfish Acanthaster planci in that the inductive ability of highly inductive shards of the alga is reduced dramatically by pretreatment with antibiotics (Johnson et al. 1991).

Critical testing of the 2 hypotheses requires isolating the alga from its epiphytic bacteria, and examining the inductive ability of the CCA and bacteria separately. However it needs to be cautioned that bioassays using 
bacteria isolated from CCA, and experiments in which CCA are treated with antibiotics, are useful only if their results are positive, since negative results must be equivocal. Because plate-viable bacteria comprise a small fraction of the total population (see Kaneko et al. 1978, Davis et al. 1983, Hobbie 1988), the great majority of bacteria cannot be isolated and tested for inducing ability. Also, many marine bacteria are resistant to antibiotics (e.g. using the plate-viable method of Lewis et al. 1985, treatment of CCA with $50 \mu \mathrm{g} \mathrm{m} \mathrm{m}^{-1}$ penicillin plus $50 \mu \mathrm{g} \mathrm{ml} \mathrm{m}^{-1}$ neomycin sulphate for $3 \mathrm{~d}$ reduced bacterial $\log$ counts to $5.3 \pm 0.5$ compared to counts of $6.3 \pm 0.5$ on controls; C.D. Garland unpubl.). Thus, inability of antibiotics to influence settlement rates on CCA can indicate that morphogens originate either from the algae, or from bacteria resistant to antibiotics, or both. Given these limitations we suggest that the critical (if onerous) experiment to refute the hypothesis of bacterial origin is to conduct bioassays under sterile conditions using axenically cultured (intact) coralline algae.

Finally, it needs to be emphasized that the 2 hypotheses are not mutually exclusive. The source of inducers of some species may be algal, and of others, bacterial. It is possible that morphogens derived from either algae or associated bacteria will induce larvae of a given species. In the context of induction of Haliotis larvae, it is neither required nor precluded that inducers of microbial origin (if they exist) are identical to those identified by Morse and colleagues; although their significant work has identified a single class of protein-oligopeptide complex, it is possible that in preparing extracts, algal-derived products dilute those from bacteria to undetectable levels.

\section{No evidence of free GABA or L-DOPA from corallines or bacteria}

There are several marine invertebrates for which it has been documented that both GABA and CCA induce settlement and metamorphosis of planktonic larvae; larvae of other species are induced by L-DOPA or DOPA-related compounds (see 'Introduction'). These findings have raised the question of whether free GABA and L-DOPA have any ecological relevance. Present evidence indicates that GABA is not involved in the induction of Haliotis rufescens larvae in nature (Morse \& Morse 1984b, A. Morse pers. comm.). Similarly, there is no documentation of the ecological relevance of L-DOPA as a morphogen, although it has been found in conjugated form in the marine environment (Waite 1990), Our inability to detect either GABA of L-DOPA in cell-free extracts of Sporolithon sp. or Clathromorphum sp., or the bacteria isolated from them and from adjacent microhabitats, adds weight to the evidence that these compounds have no ecological relevance in induction of marine larvae. It is unlikely that there is any ecological connection between observations showing induction of marine larvae by both GABA and coralline algae.

Acknowledgements. We thank Jean Harris, and Muffy and Robin Seiderer who did all the SEM work; Rob Anderson, Paul Hanekom, Andrea Pulfrich and Steve Tugwell for assistance in the field; Yvonne Chamberlain for identifying the coralline algae; Chris Field for advice on statistics; Christian Garland for providing data on effectiveness of antibiotics on CCAassociated bacteria; and Aileen Morse, Dan Alongi, Rebecca Jensen, and 2 anonymous reviewers for critical reading of the manuscript. Muffy Seiderer provided valuable advice throughout the study. The work was undertaken while C.R.J. was in receipt of a Post Doctoral Fellowship from the University of Cape Town, and was funded by a South African Foundation for Research and Development team grant awarded to George Branch, John Field and Charles Griffith.

\section{LITERATURE CITED}

Arnow, J. (1937). Colorimetric determination of the components of 3,4-dihydroxyphenylalanine-tyrosine mixtures. J. biol Chem. 118: 531-537

Barker, M. F. (1977). Observations on the settlement of the brachiolaria larvae of Stichaster australis (Verrill) and Coscinasterias calamaria (Gray) (Echinodermata: Asteroidea) in the laboratory and on the shore. J. exp. mar. Biol. Ecol. 30: $95-108$

Barnes, J. R., Gonor, J. J. (1973). The larval settling response of the lined chiton Tonicella lineata. Mar. Biol. 20: 259-264

Belbin, L. (1987). PATN pattern analysis package. CSIRO, Australia

Brancato, M. S., Woollacott, R. M. (1982). Effect of microbial films on settlement of bryozoan larvae (Bugula simplex, $B$. stolonifera, and B. turrita). Mar Biol. 71: 51-56

Bray, J. R., Curtis, J. T (1957). An ordination of the upland forest communities of southern Wisconsin. Ecol. Monogr. 27: $325-349$

Breitburg, D. L. (1984). Residual effects of grazing: inhibition. of competitor recruitment by encrusting coralline algae. Ecology 65: 1136-1143

Cameron, R. A., Hinegardner, R. T (1974). Initiation of metamorphosis in laboratory cultured sea urchins. Biol Bull. mar biol. Lab., Woods Hole 146: 335-342

Clifford, H. T., Stephenson, W (1975). An introduction to numerical classification. Academic Press, New York

Coon, S. L., Bonar, D. B., Weiner, R. M. (1985). Induction of settlement and metamorphosis of the Pacific oyster, Crassostrea gigas (Thunberg), by L-DOPA and catecholamines. J. exp. mar. Biol. Ecol., 94: 211-221

Cooper, K. (1983). Potential for application of the chemical DOPA to commercial bivalve setting systems. J. Shellfish Res. 3: 110-111

Davis, C. L., Koop, K., Muir, D. G., Robb, F. T (1983). Bacterial diversity in adjacent kelp-dominated ecosystems. Mar Ecol. Prog. Ser. 13: 115-119

Faith, D. P., Minchin, P. R., Belbin, L. (1987). Compositional similarity as a robust measure of ecological distance a theoretical model and computer simulations. Vegetatio 69 $57-68$ 
Field, J. G., Clarke, K. R., Warwick, R. M. (1982). A practical strategy for analysing multispecies distribution patterns. Mar Ecol. Prog. Ser 8: 37-52

Fitt, W K., Hofmann, D. K., Wolk, M., Rahat, M. (1987). Requirement of exogenous inducers for metamorphosis of axenic larvae and buds of Cassiopea andromeda (Cnidaria: Scyphozoa). Mar Biol. 94: 415-422

Fitt, W. K., Labare, M. P., Fuqua, W. C., Walch, M., Coon, S. L. Bonar, D. B., Colwell, R. R., Weiner, R. M. (1989). Factors influencing bacterial production of inducers of settlement behaviour of larvae of the oyster Crassostrea gigas. Microb. Ecol. 17: 287-298

Garbary, D., Veltkamp, C. J. (1980). Observations on Mesophyllum lichenoides (Corallinaceae, Rhodophyta) with the scanning electron microscope. Phycologia 19: $49-53$.

Garland, C. D., Cooke, S. L., Grant, J. F., McMeekin, T A. (1985). Ingestion of the bacteria on and the cuticle of crustose (non-articulated) coralline algae by post-larval and juvenile abalone (Haliotis ruber Leach) from Tasmanian waters. J. exp. mar. Biol. Ecol, 91: 137-149

Gee, J. M. (1965). Chemical stimulation of settlement in larvae of Spirorbis rupestris (Serpulidae). Anim. Behav. 13: $181-186$

Gray, J. S. (1966). The attractive factor of intertidal sands to Protodrilus symbioticus. J. mar. biol. Ass. U.K. 46: 627-645

Gray, J. S. (1967). Substrate selection by the archiannelid Protodrilus rubropharyngeus. Helgoländer wiss Meeresunters. 15: 253-269

Hahn, K. O. (1989). Induction of settlement in competent abalone larvae. In: Hahn, K. O. (ed.) Handbook of culture of abalone and other marine gastropods. CRC Press, Florida, p. 101-112

Hobbie, J. E. (1988). A comparison of the ecology of planktonic bacteria in fresh and salt water. Limnol. Oceanogr 33: $750-764$

Hofmann, D. K., Brand, U. (1987). Induction of metamorphosis in the symbiotic scyphozoan Cassiopea andromeda; role of marine bacteria and biochemicals. Symbiosis 4: 99-116

Hofmann, D. K., Neumann, R., Henne, K. (1978). Strobilation, budding and initiation of scyphistoma morphogenesis in the rhizostome Cassiopea andromeda (Cnidaria: Scyphozoa). Mar. Biol. 47: 161-176

Jensen, R. A., Morse, D. E. (1984). Intraspecific facilitation of larval recruitment: gregarious settlement of the polychaete Phragmatopoma californica (Fewkes). J. exp. mar. Biol. Ecol. 83: 107-126

Jensen, R. A., Morse, D. E. (1990). Chemically induced metamorphosis of polychaete larvae in both the laboratory and ocean environment. J. chem. Ecol. 16: 911-930

Johnson, C. R., Mann, K. H. (1986). The crustose coralline alga, Phymatolithon Foslie, inhibits the overgrowth of seaweeds without relying on herbivores. J. exp. mar. Biol. Ecol. 96: 127-146

Johnson, C. R., Sutton, D. C., Olson, R. R., Giddins, R. (1991). Settlement of crown-of-thorns starfish: role of bacteria on surfaces of crustose coralline algae and a hypothesis for deepwater recruitment. Mar. Ecol. Prog. Ser. 71: 143--162

Kaneko, T., Hauxhurst, J., Krichevsky, M., Atlas, R. M. (1978). Numerical taxonomic studies of bacteria isolated from arctic and sub-arctic marine environments. In: Loutit, M. W., Miles, J.A.R. (eds.) Microbial ecology. Springer Verlag, Berlin, p. 26-30

Kirchman, D., Graham, S., Reish, D., Mitchell, R. (1982). Bacteria induce settlement and metamorphosis of Janua (Dexiospira) Brasiliensis Grube (Polychaeta: Spirorbidae). J. exp. mar. Biol. Ecol. 56: 153-163
Lewis, T. E., Garland, C. D., McMeekin, T A. (1985). The bacterial biota on crustose (nonarticulated) coralline algae from Tasmanian waters. Microb. Ecol. 11. 221-230

McShane, P. E., Smith, M. G. (1988). Measuring recruitment of abalone Haliotis rubra Leach (Gastropoda: Haliotidae) comparison of a novel method with two other methods. Aust. J. mar Freshwat. Res. 39: 331-336

Mihm, J. W., Banta, W. C., Loeb, G. I. (1981). Effects of adsorbed organic and primary fouling films on bryozoan settlement. J. exp. mar. Biol. Ecol, 54: 167-179

Morse, A. N. C. (1985) Characterisation of inducers of molluscan larval metamorphosis. Ph. D. dissertation, University of California, Santa Barbara

Morse, A. N. C., Froyd, C. A., Morse, D. E. (1984). Molecules from cyanobacteria and red algae that induce larval settlement and metamorphosis in the mollusc Haliotis rufescens. Mar. Biol. 81: 293-298

Morse, A. N. C., Morse, D. E. (1984a). Recruitment and metamorphosis of Haliotis larvae induced by molecules uniquely available at the surfaces of crustose red algae. $J$. exp. mar. Biol. Ecol. 75: 191-215

Morse, A. N. C., Morse, D. E. (1984b). GABA-mimetic molecules from Porphyra (Rhodophyta) induce metamorphosis of Haliotis (Gastropoda) larvae. Hydrobiologia 116/117: 155-158

Morse, D. E., Duncan, H., Hooker, N., Baloun, A., Young, G. (1980). GABA induces behavioural and developmental metamorphosis in planktonic molluscan larvae. Fed. Proc. 39: $3237-3241$

Morse, D. E., Hooker, N., Duncan, H., Jensen, L. (1979). $\gamma$ aminobutyric acid, a neurotransmitter, induces planktonic abalone larvae to settle and begin metamorphosis. Science 204: $407-410$

Morse, D. E., Hooker, N., Morse, A. N. C., Jensen, R. A (1988). Control of larval metamorphosis and recruitment in sympatric agariciid corals. J. exp. mar. Biol. Ecol. 116: 193-217

Neumann, R. (1979). Bacterial induction of settlement and metamorphosis in the planula larvae of Cassiopea andromeda (Cnidaria: Scyphozoa, Rhizostomeae). Mar. Ecol. Prog. Ser. 1: 21-28

Padilla, D. K. (1981). Selective agents influencing the morphology of coralline algae. M. Sc. dissertation, Oregon State University, Corvallis

Pawlik, J. R. (1990). Natural and artificial induction of metamorphosis of Phragmatopoma lapidosa californica (Polychaeta: Sabellariidae), with a critical look at the effects of bioactive compounds on marine invertebrate larvae. Bull. mar. Sci. 46: 512-536

Pearce, C. M., Scheibling, R. E. (1988). Larval settlement in the green sea urchin, Strongylocentrotus droebachiensis. Am. Zool. 28: 365

Prince, J. D., Sellers, T. L., Ford, W. B., Talbot, S. R. (1987). Experimental evidence for limited dispersal of haliotid larvae (genus Haliotis; Mollusca: Gastropoda). J. exp. mar. Biol. Ecol. 106: 243-263

Raj, H. D. (1981). The genus Microcyclus and related bacteria. In: Starr, M. P., Stolp, H., Truper, H. G., Balows, A., Schlegel, H. G. (eds.) The prokaryotes, Vol. 1., SpringerVerlag, Berlin, p. 630-644

Rohlf, F. J. (1982). BIOM, a package of statistical programs to accompany the text Biometry. Freeman, San Francisco

Rowley, R. (1989). Settlement and recruitment of sea urchins (Strongylocentrotus spp.) in a sea-urchin barren ground and a kelp bed: are populations regulated by settlement or post-settlement processes? Mar. Biol. 100: 484-494

Rumrill, S. S., Cameron, R. A. (1983). Effects of gamma- 
aminobutyric acid on the settlement of larvae of the black chiton Katharina tunicata. Mar. Biol. 72: 243-247

Saito, K. (1981). The appearance and growth of 0-year-old Ezo abalone. Bull. Jpn Soc scient. Fish. 47-1393-1400

Sebens, K. P. (1983a). Settlement and metamorphosis of a temperate soft-coral larva (Alcyonium siderium Verrill): induction by crustose algae. Biol. Bull. mar, biol. Lab., Woods Hole 165: 286-304

Sebens, K. P. (1983b). The larval and juvenile ecology of the temperate octocoral Alcyonium siderium Verrill. I. Substratum selection. J. exp. mar. Biol. Ecol. 70: 1-17

Sieburth, J. M., Pratt, H. L., Johnson, P. W., Scales, D. (1975). Microbial seascapes - a pictorial essay of marine microorganisms and their environments. University Park Press, Baltimore

Shepherd, S. A. Turner, I. A. (1985). Studies on southern Australian abalone (genus Haliotis). VI. Habitat preference and abundance and predators of juveniles. J. exp. mar. Biol. Ecol. 93: 285-298

This article was presented by D. Klumpp, Townsville, Australia
Sokal, R. R., Rohlf, F. J. (1981). Biometry, 2nd edn. Freeman San Francisco

Steneck, R. S. (1982). A limpet-coralline alga association. adaptations and defenses between a selective herbivore and its prey. Ecology 63: 507-522

Waite, J. H. (1990). The phylogeny and chemical diversity of quinone-tanned glues and varnishes. Comp. Biochem. Physiol. 97B: 19-29

Weiner, R. M., Segall, A. M., Colwell, R. R. (1985). Characterization of a marine bacterium associated with Crassostrea virginica (the eastern oyster). Appl. environ. Microbiol 49 : 83-90

Williams, W. T (1976). Pattern analysis in agricultural science. CSIRO, Melbourne

Yamaguchi, M. (1973). Early life histories of coral reef asteroids, with special reference to Acanthaster planci (L.). In: Jones, O. A., Endean, R. (eds.) Biology and ecology of coral reefs, Vol. II: Biology 1. Academic Press, New York, p. $369-387$

Manuscript first received: May 11, 1990

Revised version accepted: April 8, 1991 